\title{
Magnetic constraints on the subsurface structure of Akita-Yakeyama volcano, northeast Japan
}

\author{
Shigeo Okuma \\ Geological Survey of Japan, Higashi 1-1-3, Tsukuba, Ibaraki 305-8567, Japan \\ (Received February 17, 1997; Revised September 24, 1997; Accepted November 21, 1997)
}

\begin{abstract}
Magnetic analyses have been conducted in and around Akita-Yakeyama volcano at the northwestern edge of the Sengan Geothermal Area, northeast Japan to reveal the regional and local subsurface structures of the area. First, a magnetization intensity mapping method has been applied to analyze aeromagnetic anomalies of the area. Generally, magnetization highs and lows lie on volcanic rocks which are normally and reversely magnetized, respectively. Magnetization lows with small amplitudes are distributed on hydrothermally altered areas. These results imply the usefulness of the method to estimate the young volcanic activities of Quaternary volcanic areas. Detailed magnetic modeling reveals the subsurface structure of Akita-Yakeyama volcano itself. Rock magnetic data from volcanic rocks, both from the surface and cores in the geothermal exploration wells, have been employed for the modeling. The resultant magnetic structure indicates the following: the surface volcanic rocks are underlain by granitic intrusions which have minimum thicknesses of about 2,000 m below the northern flank of volcano; in the southern flank, the surface volcanic rocks are underlain widely by the Old-Tamagawa Welded Tuffs which are reversely magnetized. These results show a good agreement with a geologic interpretation in and around the volcano, especially with a hypothesis of the existence of buried calderas below the present volcano.
\end{abstract}

\section{Introduction}

Akita-Yakeyama volcano is situated at the northwestern edge of the Sengan Geothermal Area, northeast Japan, where many geothermal features such as fumaroles and hot springs are observed as well as many Quaternary volcanoes (Fig. 1). In late 1970s, an aeromagnetic survey was conducted in the area by (Ministry of International Trade and Industry (MITI), 1978); successive analyses of the magnetic anomalies were conducted to make a regional magnetic model which accounts for the anomalies (MITI, 1978; Okuma and Suto, 1987). Okuma and Suto (1987) calculated correlation coefficients between the observed and synthetic magnetic anomalies (Blakely and Grauch, 1983) and showed that the rocks in the regions of positive correlation are normally magnetized and those in the regions of negative correlation are reversely magnetized. They also conducted a spectral analysis of the magnetic anomalies to estimate the depth to the magnetic basement, indicating that the magnetic basement is shallower in the center of the area than in the edges of the area. However, their analyses were focused primarily on revealing the regional distribution of the direction of the magnetization of the volcanic rocks which compose the magnetic terrain and regional subsurface structure of the area. Recently a new geothermal power plant began operation around Akita-Yakeyama volcano as a result of intensive geothermal explorations. Therefore, more detailed analyses and interpretations of the magnetic anomalies are necessary for revealing the detailed subsurface structure of the vol-

Copy right (C) The Society of Geomagnetism and Earth, Planetary and Space Sciences (SGEPSS); The Seismological Society of Japan; The Volcanological Society of Japan; The Geodetic Society of Japan; The Japanese Society for Planetary Sciences. cano and its surrounding areas. New techniques of the analysis of the magnetic anomalies and accumulated other geophysical data including paleomagnetic data make it possible to conduct such a study.

\section{Geology}

Recently, detailed geologic maps have been compiled for the Sengan Geothermal Area (Research group for the geological map of Sengan Geothermal Area, 1985) and for Akita-Yakeyama volcano and its surrounding areas (Suto, 1992), respectively. These maps show that the geothermal area is covered widely by Quaternary volcanic rocks with outcrops of Pleistocene ones (Fig. 2). Drilling showed that the surface volcanic rocks are underlain by Neogene volcanic and sedimentary rocks in the Sengan Geothermal Area. The absence of pre-Neogene rocks inside the geothermal area and the presence of Paleozoic sedimentary rocks and Cretaceous granitic rocks outside the area suggest the existence of a large tectonic subsidence beneath the surface volcanic rocks.

According to an explanation of the geologic map of AkitaYakeyama volcano (Suto, 1992), the geology and tectonics of the volcano are summarized as follows:

Akita-Yakeyama volcano is considered to be younger than 1 Ma by K-Ar dating, a paleomagnetic study and volcanostratigraphy. Most of the volcanic rocks from the volcano are quartz and/or olivine-bearing pyroxene andesite, whereas small amounts of them are composed of dacite and rhyolite. A piston cylinder type depression is observed right beneath Akita-Yakeyama volcano, which is named as the Pre-Yakeyama caldera, and is considered to have collapsed during the eruption of the Tamagawa Welded Tuffs. An- 


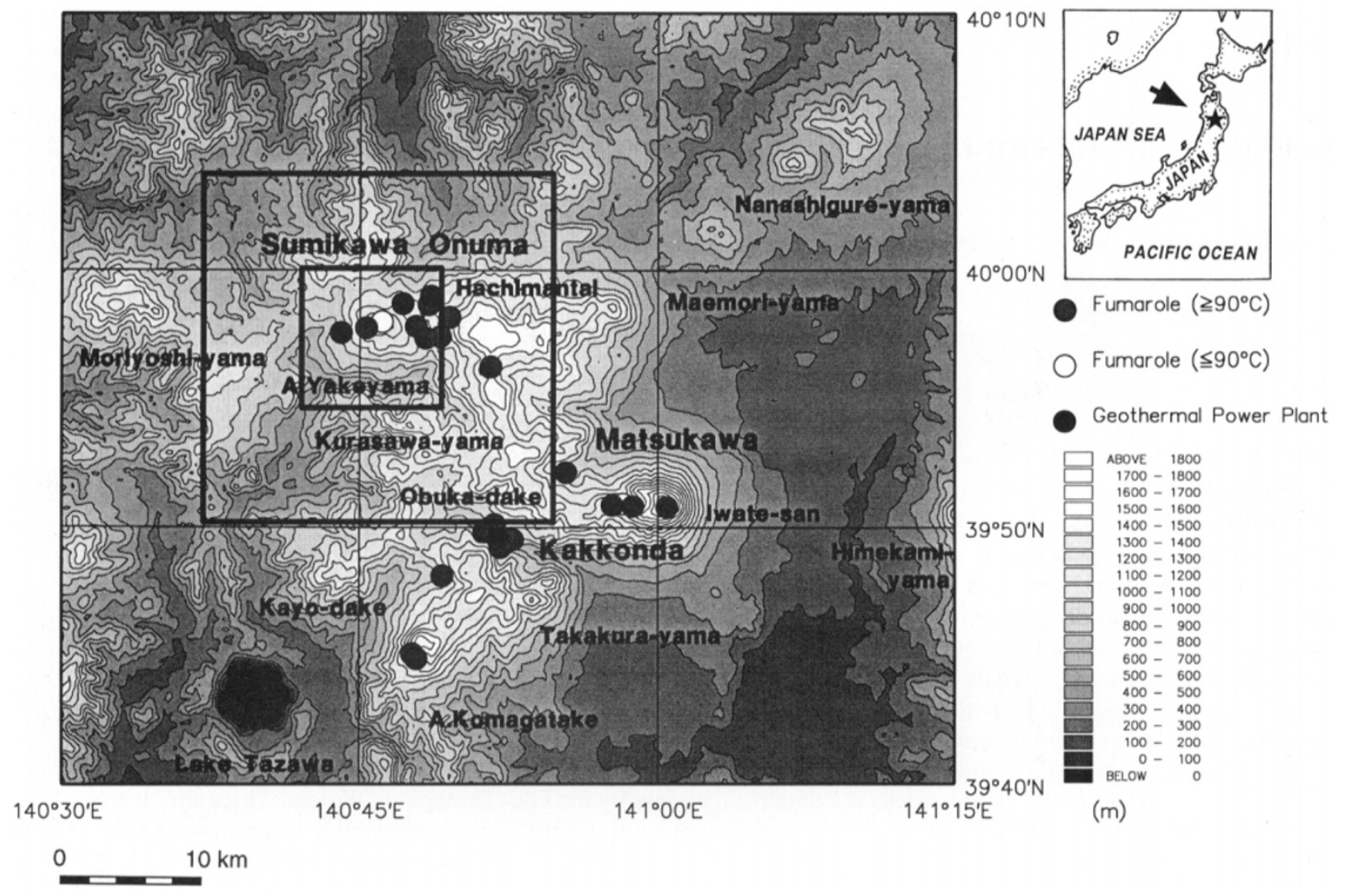

Fig. 1. Topographic map of the Sengan Geothermal Area. Contour interval is $100 \mathrm{~m}$. The large and small boxes show the close-up and the detail study area of Akita-Yakeyama volcano, respectively.
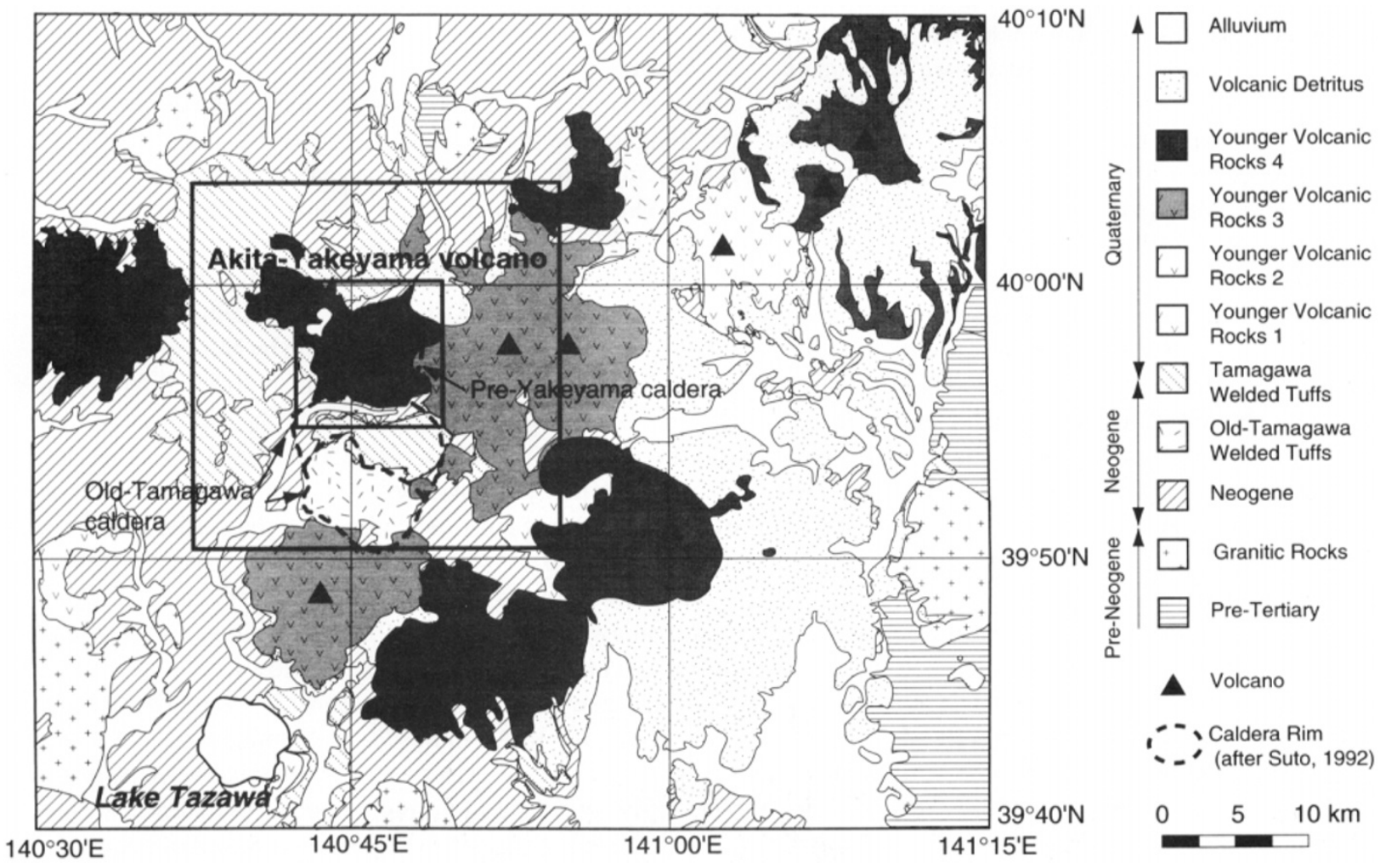

Fig. 2. Geological map of the Sengan Geothermal Area modified from Research group for the geologic map of Sengan Geothermal Area (1985). Younger Volcanic Rocks 1: Matsukawa Andesite, Younger Volcanic Rocks 2: Otsuki-yama volcanics, Younger Volcanic Rocks 3: Hachimantai volcanics and Kayo-dake volcanics, Younger Volcanic Rocks 4: Nanashigure-yama volcanics, Takakura-yama volcanics, Moriyoshi-yama volcanics, Akita-Yakeyama volcanics, Iwate-san volcanics and Akita-Komagatake volcanics. 
other caldera is also recognized south of the volcano: the Old-Tamagawa caldera. The caldera is thought to have collapsed during the eruption of the Old-Tamagawa Welded Tuffs in the Neogene, resulting two stage depressions filled up with welded tuffs with the thicknesses exceeding 1,000 $\mathrm{m}$.

\section{Geologic Factors on Geothermal Explorations}

Geothermal convection systems (White, 1967; Fig. 3) are dominant in the Sengan Geothermal Area. Fracture systems are expected to exist along fault systems and/or geologic boundaries between the basement and overlaying layers. Therefore, revealing concealed fault systems and structures of the basement are important for geothermal exploration in the area. A regional fault system, the Hanawa graben, lies north and south between Akita-Yakeyama and Hachimantai volcanoes. The Onuma geothermal power plant is located in the center of the graben, while the Sumikawa geothermal power plant lies at the western edge of the graben (Fig. 1; Komazawa, 1987).

High-temperature geothermal fluids associated with fractures cause hydrothermal alterations of the rocks which compose volcanic terrains and are essential for power generation in this area. Mapping of hydrothermally altered areas on the surface has been conducted by geologists but needs to be done beneath the surface.

Hot intrusive bodies are sometimes direct heat sources of geothermal activities but are not common in the area except Matsukawa area, where a geothermal power plant is under operation by employing vapor dominated resources.

Important geologic factors on geothermal explorations in the Sengan Geothermal Area are summarized as follows: regional and local fault systems, structures of the basement, hydrothermally altered areas, and hot intrusive rocks. In this paper, I will discuss a mapping of hydrothermally altered areas in the Sengan Geothermal Area by employing an inversion of magnetic anomalies and a magnetic modeling of the subsurface structure of Akita-Yakeyama volcano.

\section{Magnetization Intensity Mapping}

In conjunction with various geophysical surveys, an aeromagnetic survey for geothermal exploration was conducted in the Sengan Geothermal Area (MITI, 1978). Okuma and Suto (1986) recompiled aeromagnetic anomaly maps from the original anomaly data. The observed magnetic anomalies (Fig. 4) are influenced strongly by the effect of topographic relief. The volcanic rocks which compose the terrain have their magnetic properties, strong enough to cause intensive magnetic anomalies.

To remove the effects of magnetic terrain, I applied an apparent magnetization intensity mapping method (Okuma et al., 1994a; Nakatsuka, 1995) to the magnetic anomalies of the Sengan Geothermal Area. These methods were useful for revealing concealed old volcanic edifices on Izu-Oshima Island (Okuma et al., 1994a) and the quadratic distribution pattern of magnetization intensity along the Tanna fault, presumably caused by movements of the strike-slip fault (Nakatsuka, 1995).

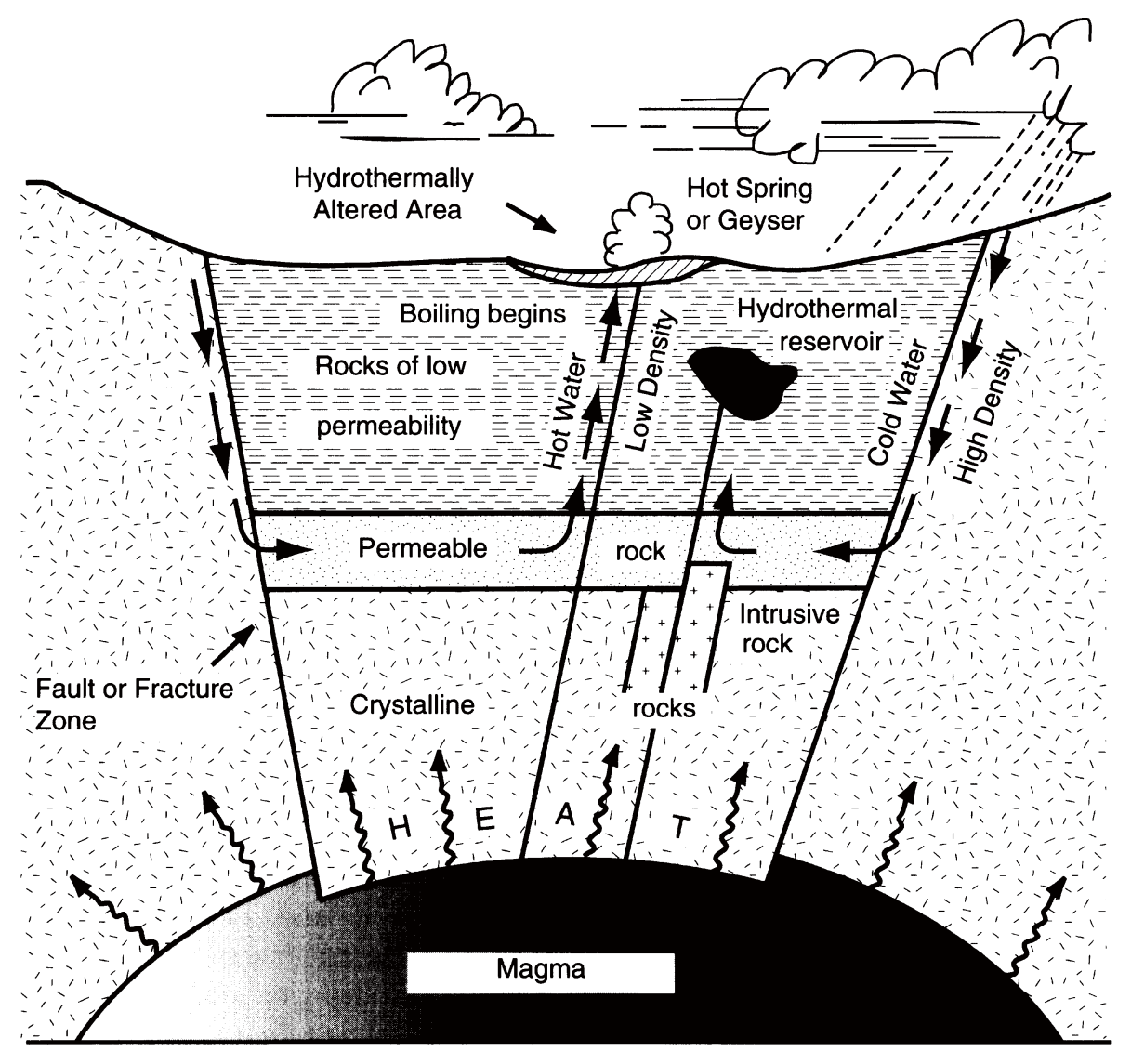

Fig. 3. Generalized model of a geothermal convection system, modified from White (1967). 


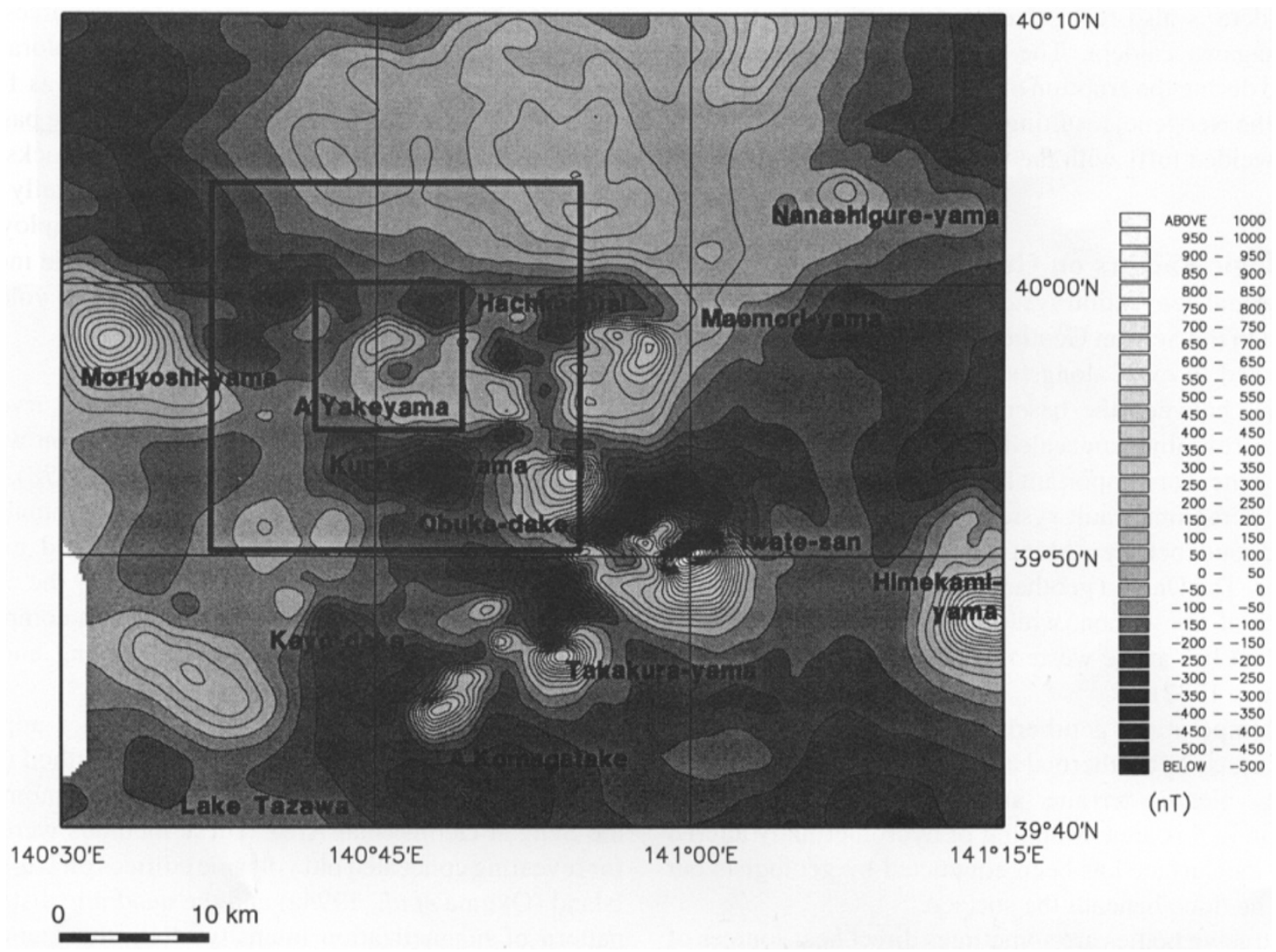

Fig. 4. Total intensity aeromagnetic anomalies (IGRF residuals) in the Sengan Geothermal Area. Contour interval is $50 \mathrm{nT}$. The altitude of datum plane is $1,800 \mathrm{~m}$ Above Sea Level. See also Fig. 1 .

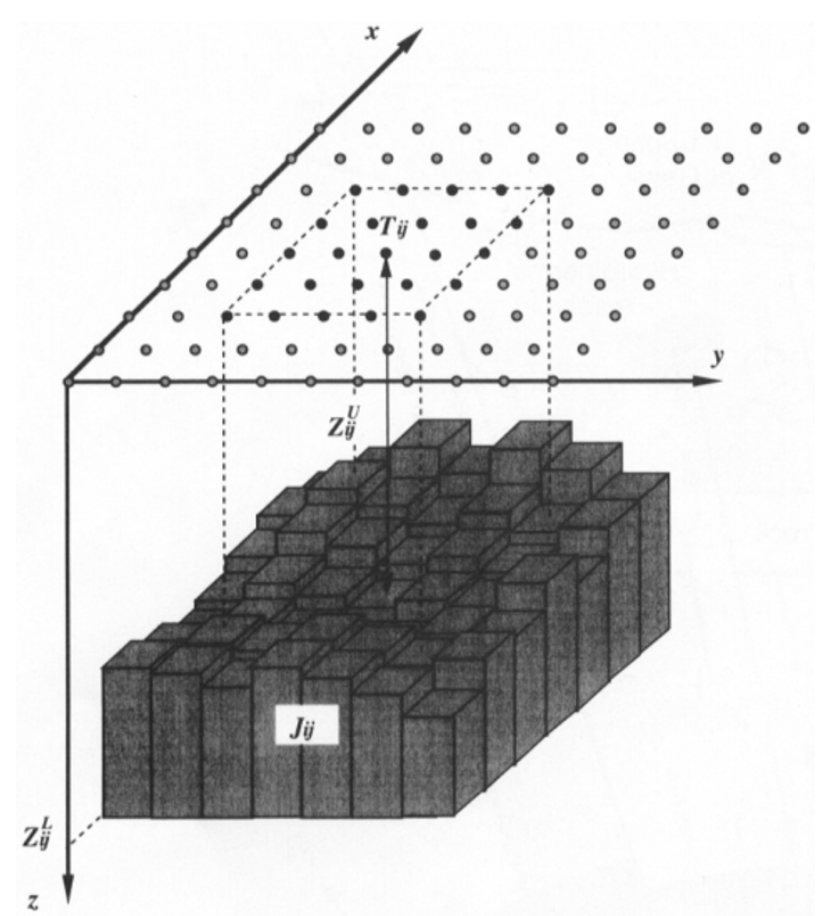

Fig. 5. Magnetic model employed for an apparent magnetization intensity mapping in this study. $J_{i j}$ : Magnetization of a prism at $i j$-th point, $T_{i j}$ : Synthetic magnetic anomaly at $i j$-th point, $Z_{i j}{ }^{\mathrm{U}}$ : Top depth of a prism at $i j$-th point, $Z_{i j}$ : Bottom depth of a prism at $i j$-th point.
I assume a magnetic model composed of finite rectangular prisms that corresponds to the volcanic terrain (Fig. 5). The top depth of the model corresponds to the ground surface, while the bottom depth corresponds to a flat surface, though it can be assumed to be of any shape. In this case, the synthetic magnetic anomaly $T_{x}$ can be formulated by Eq. (1).

$$
T_{x}=\sum_{i=1}^{m} W_{x i} J_{i} \quad(x=1,2, \ldots, n)
$$

where $W_{x i}$ : Geometrical factor from the $x$-th point against the $i$-th prism (Bhattacharyya, 1964); $J_{i}$ : Magnetization of $i$-th prism.

The observed magnetic anomaly $F_{x}$ can be formulated in Eq. (2).

$$
\sum_{i=1}^{m} W_{x i} J_{i}=F_{x} \quad(x=1,2, \ldots, n)
$$

If $m=n$, it is straight forward to solve this equation because it has a unique solution. Nevertheless, the solution sometimes reveals an oscillation in an ill-conditioned case, probably due to the accumulation of numerical error. Therefore, I employ the conjugate gradient method (Nakatsuka, 1995) instead of solving Eq. (2) directly. A flat surface of $5 \mathrm{~km}$ below sea level was used for the bottom depth of the magnetic model, taking account of a local shallow Curie 


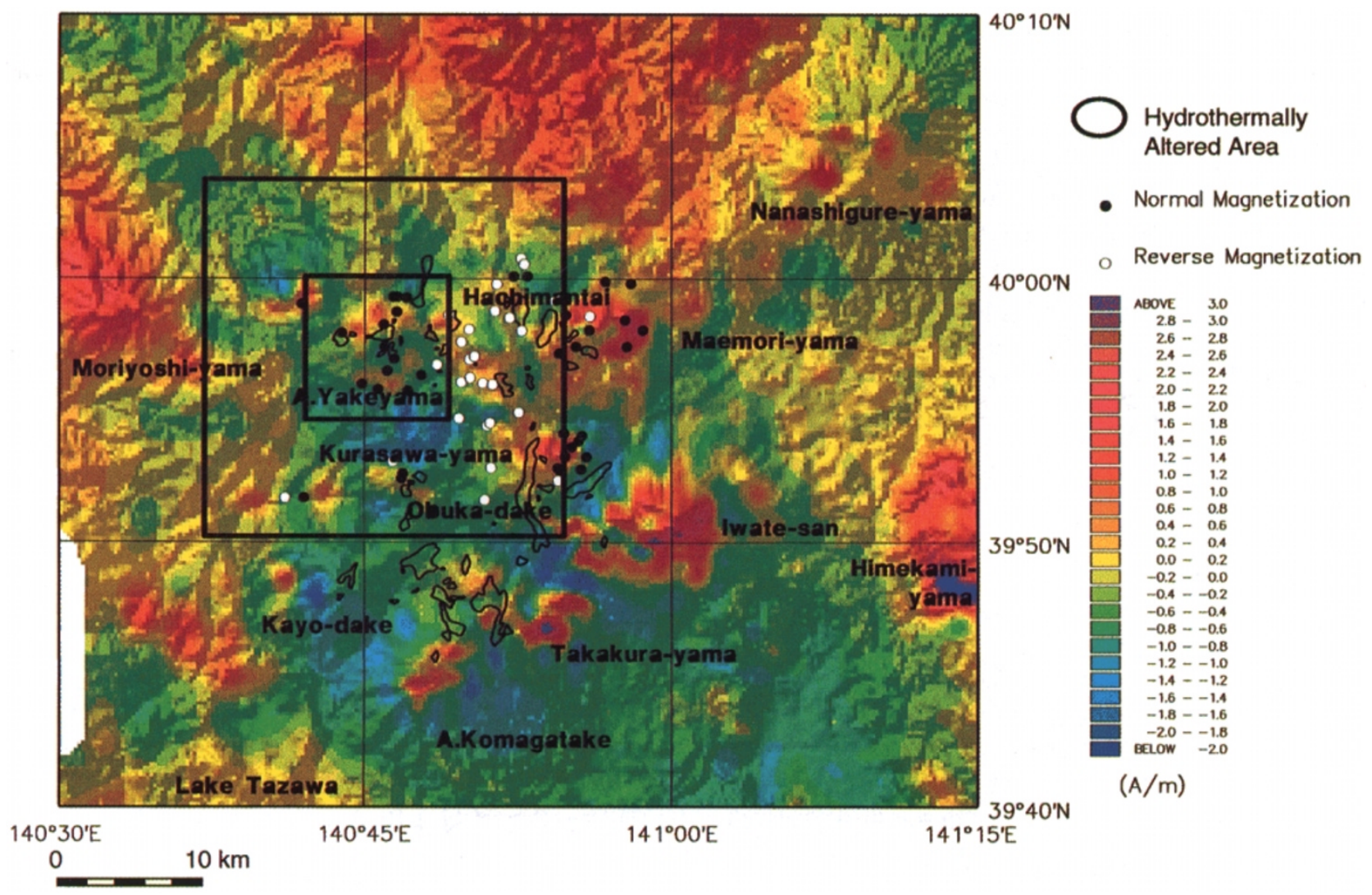

Fig. 6. Magnetization intensity map of the Sengan Geothermal Area with a topographic shading. Contour interval is $0.2 \mathrm{~A} / \mathrm{m}$. The areas bounded by solid lines indicate hydrothermal altered areas. Solid and open circles locate volcanic rocks which are normally and reversely magnetized, respectively. Paleomagnetic data (Suto, 1985, 1987, 1992; Suto and Mukoyama, 1987) which have stable magnetization intensities ( $\geq 1.0 \mathrm{~A} / \mathrm{m}$ ) with magnetic pole latitudes $\left(\geq\left| \pm 50^{\circ}\right|\right)$ were plotted. See also Fig. 1.

$140^{\circ} 45^{\prime} \mathrm{E}$

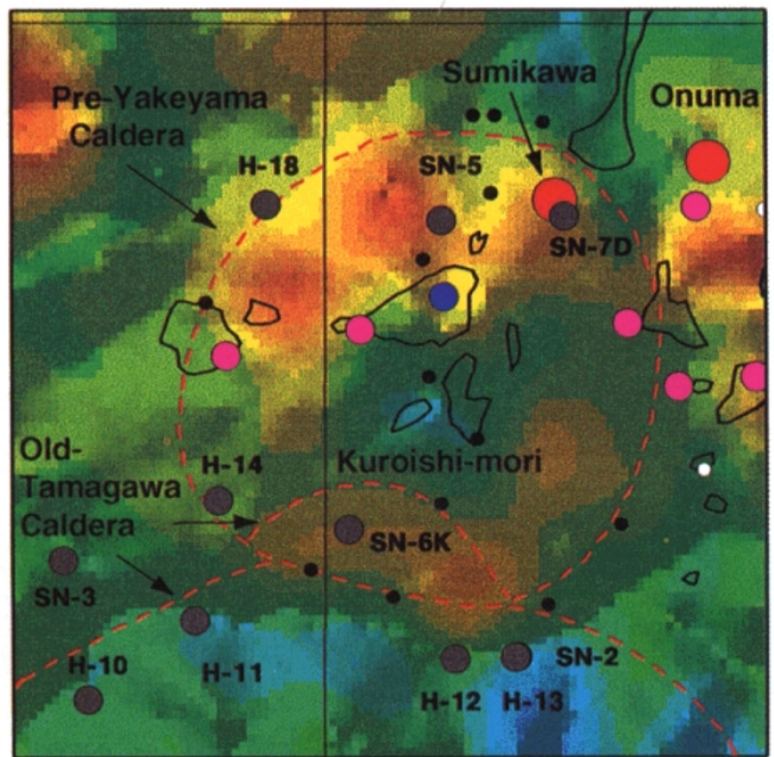

$5 \mathrm{~km}$ $40^{\circ} 00^{\prime} \mathrm{N}$

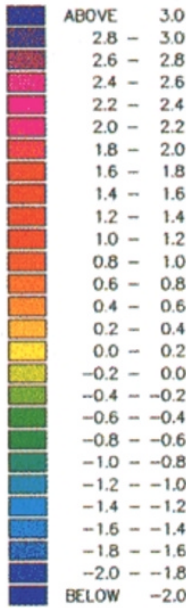

Hydrothermally Altered Area

\section{$\therefore$; Caldera Rim}

- Normal Magnetization

- Reverse Magnetization

Fumarole $\left(\geqq 90^{\circ} \mathrm{C}\right)$

Fumarole $\left(\leqq 90^{\circ} \mathrm{C}\right)$

Geothermal Power Plant

Geothermal Explor. Well
0

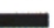

Fig. 7. Magnetization intensity map of Akita-Yakeyama volcano with a topographic shading. The map area corresponds to the small box in Figs. 1 and 6. Contour interval is $0.2 \mathrm{~A} / \mathrm{m}$. Red broken lines indicate caldera rims of the Pre-Yakeyama caldera (north) and the Old-Tamagawa caldera (south). See also Fig. 6. 
depth $(<8 \mathrm{~km})$ (Okubo et al., 1989).

Characteristics of the distribution of the magnetization intensity (Fig. 6) are summarized as follows:

Magnetization highs lie obviously on Quaternary volcanoes such as Maemori-yama volcano, Iwate-san volcano, Obuka-dake volcano, Takakura-yama volcano and AkitaKomagatake volcano. This result clearly shows that each edifice is roughly magnetized in a direction of the present earth's magnetic field. On the other hand, obvious magnetization lows lie on Kurasawa-yama and Kayo-dake volcano. Paleomagnetic dada indicate that normally magnetized volcanic rocks are distributed in high magnetization areas, whereas reversely magnetized rocks are in low magnetization areas. This relationship is much clearer than that of Okuma and Suto (1987).

Magnetization lows with small amplitudes, or rather to say weak magnetization areas, correspond to hydrothermally altered areas mapped by Research group for the geological map of Sengan Geothermal Area (1985); weak magnetizations lie on and around the summit of Akita-Yakeyama volcano, between Sumikawa and Onuma, in Matsukawa and Kakkonda, between Takakura-yama and Akita-Komagatake volcanoes, etc. It is implied that hydrothermal alterations caused a loss of a large amount of magnetic minerals in volcanic rocks. This kind of relationship was also observed in Yellowstone National Park, USA (Okuma et al., 1994b).
Recently, young granitic intrusions have been found in Kakkonda area, one of weak magnetization areas, by drilling. A temperature of the bodies exceeded $600^{\circ} \mathrm{C}$ at the bottom of a drill hole close to the Kakkonda geothermal power plant. On the basis of the results, the apparent magnetization intensity method is useful to estimate the location of hydrothermal areas in Quaternary volcanic areas.

\section{Forward Modeling for Magnetic Structure of Akita-Yakeyama Volcano}

Next, I will focus especially on the magnetic anomaly (Fig. 4) and the resultant magnetization intensity (Fig. 7) in and around Akita-Yakeyama volcano. The distribution pattern of magnetization intensity of the volcano is different totally from that of typical young volcanoes in the Sengan Geothermal Area. Usually a magnetization high is distributed on the edifice of each volcano. Instead, a magnetization low lies right on the southern flank of the volcano, surrounded by magnetic highs.

In conjunction with rock magnetic data from surface volcanic rocks and core samples from geothermal exploration wells, I will try to construct a magnetic model which accounts for the magnetic anomalies. Drilling showed the existence of Tertiary granitic intrusions at an altitude of sea level below the northern flank of the volcano (NEDO, 1988; Fig. 8). Rock magnetic measurements indicate that the
West

Akita-Yakeyama

\section{East}

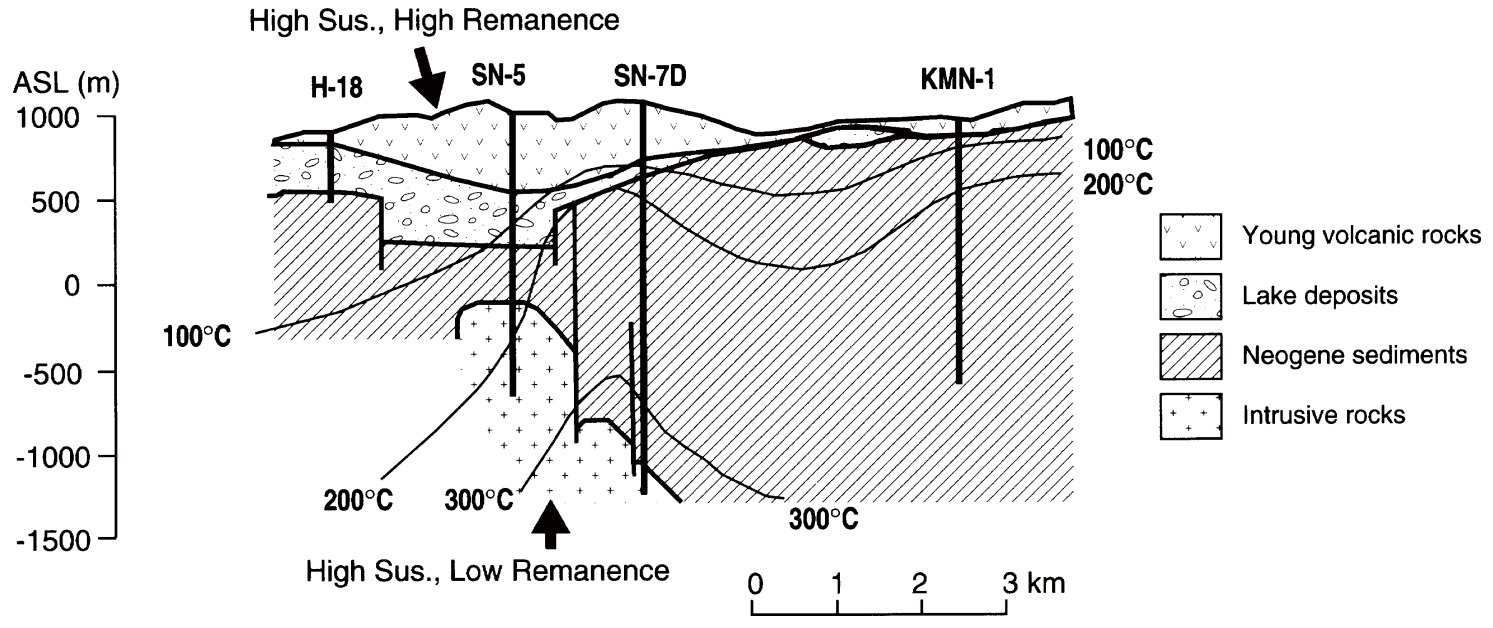

Fig. 8. E-W geologic cross section of the northern flank of Akita-Yakeyama volcano, inferred from drillings (after NEDO, 1988)

Table 1. Parameters of horizontal polygons employed for analyzing magnetic anomalies of Akita-Yakeyama volcano.

\begin{tabular}{|c|c|c|c|c|c|c|c|c|}
\hline \multirow[t]{2}{*}{ Polygon No. } & \multicolumn{3}{|c|}{ Induced magnetization } & \multicolumn{3}{|c|}{ Remanent magnetization } & \multirow{2}{*}{$\begin{array}{l}\text { Top depth } \\
\qquad \text { ASL } \\
\text { (km) }\end{array}$} & \multirow{2}{*}{$\begin{array}{c}\text { Bottom depth } \\
\text { ASL } \\
(\mathrm{km})\end{array}$} \\
\hline & $\begin{array}{l}\text { Susceptibility } \\
\text { contrast } \\
\times 10^{-2}(\mathrm{SI})\end{array}$ & $\begin{array}{l}\text { Inclination } \\
\text { (degrees) }\end{array}$ & $\begin{array}{l}\text { Declination } \\
\text { (degrees) }\end{array}$ & $\begin{array}{l}\text { Intensity } \\
\text { contrast } \\
(\mathrm{A} / \mathrm{m})\end{array}$ & $\begin{array}{l}\text { Inclination } \\
\text { (degrees) }\end{array}$ & $\begin{array}{l}\text { Declination } \\
\text { (degrees) }\end{array}$ & & \\
\hline 1 & 3.1 & 53.5 & -7.5 & 0.0 & & & 0.3 & -2.0 \\
\hline 2 & 3.1 & 53.5 & -7.5 & 0.0 & & & 0.3 & -2.0 \\
\hline 3 & 3.1 & 53.5 & -7.5 & 0.0 & & & -0.5 & -2.0 \\
\hline 4 & 0.0 & & & 2.0 & -53.5 & 172.5 & 0.7 & 0.1 \\
\hline 5 & 0.0 & & & 2.0 & -53.5 & 172.5 & 0.1 & -0.5 \\
\hline
\end{tabular}




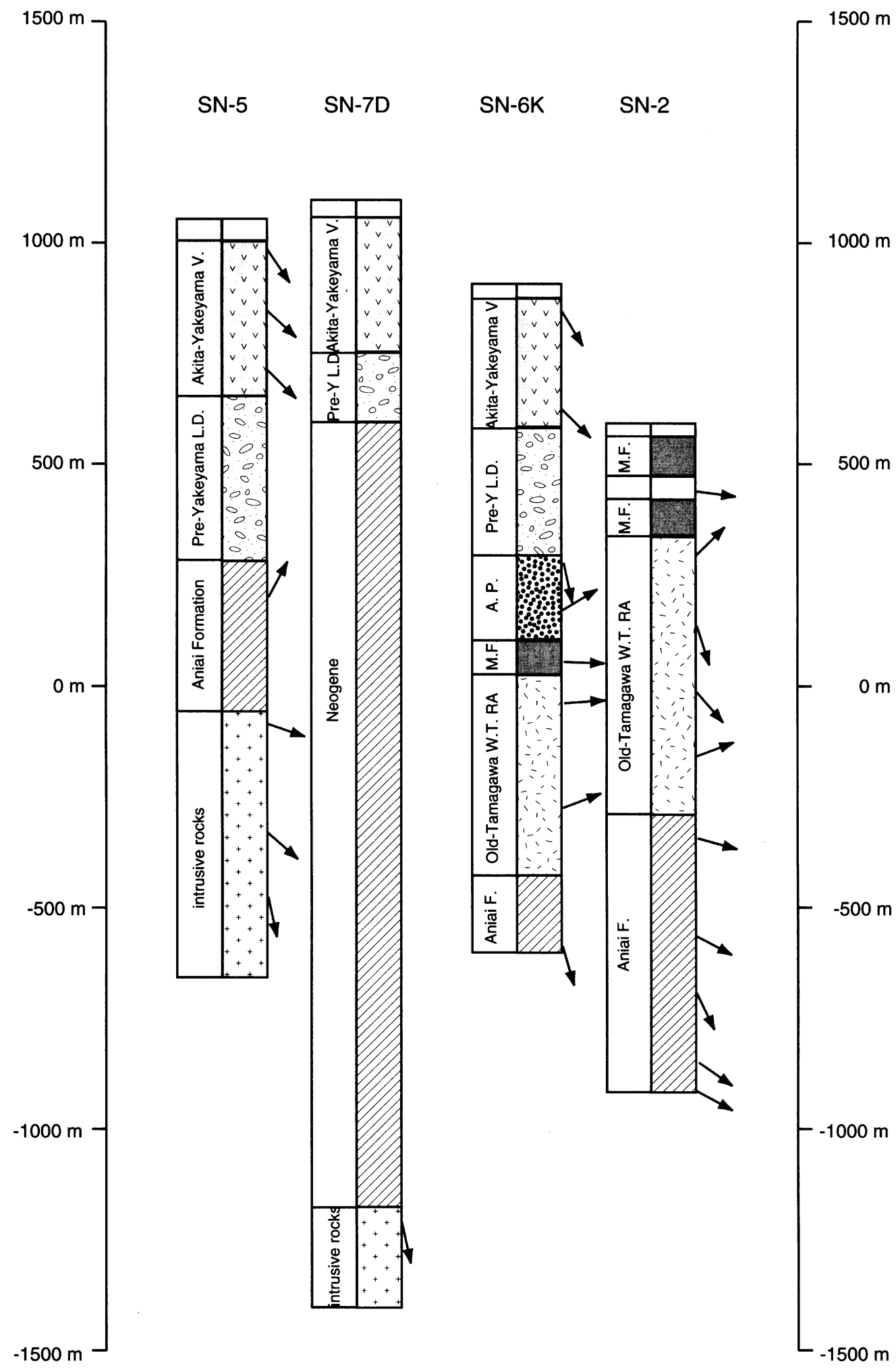

Fig. 9. Columnar section of geothermal exploration wells, SN-5, SN-7D, SN-6K and SN-2, in the northern and southern flanks of Akita-Yakeyama volcano. Vectors show inclinations of NRM of rock specimens from each unit, except for that of SN-7D (paleomagnetic inclination). A.P.: PreYakeyama Andesite Pyroclastic Rocks, M.F.: Mataguchigoya Formation (Pyroxene dacite tuff) (after Suto, 1992). See also Figs. 2 and 8.

granitic rocks have the magnetic susceptibility $(4 \pi \times 2.5 \times$ $\left.10^{-3} \mathrm{SI}\right)$ strong enough to cause intensive magnetic anomalies, though the natural remanent magnetization (NRM) of the rocks is negligibly small $\left(\leq 2 \times 10^{-1} \mathrm{~A} / \mathrm{m}\right)(\mathrm{NEDO}, 1986 \mathrm{a}$; Fig. 9). Drilling also showed that the surface volcanic rocks on the southern flank of the volcano are underlain by the
Old-Tamagawa Welded Tuffs (NEDO, 1986b). According to paleomagnetic measurements (Suto, 1985, 1987, 1992; Suto and Mukoyama, 1987), most of the Old-Tamagawa Welded Tuffs are reversely magnetized as well as the Tamagawa Welded Tuffs to the south.

Magnetic anomalies which are caused only by the volca- 


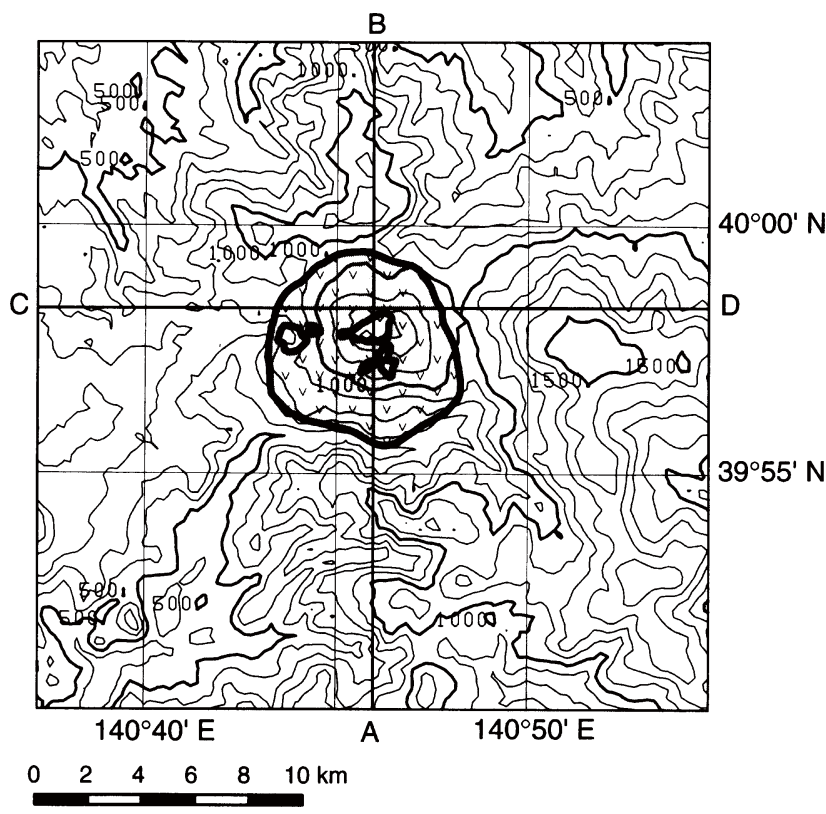

Fig. 10. Topographic map of Akita-Yakeyama volcano and its vicinity. The map area corresponds to the large box in Figs. 1 and 6. The patterned area bounded by thick solid lines indicates a terrain model which has a constant thickness of $500 \mathrm{~m}$ and its top is the ground surface, excluding hydrothermal altered areas which correspond to non magnetic areas. Contour interval is $100 \mathrm{~m}$. See also Fig. 6.

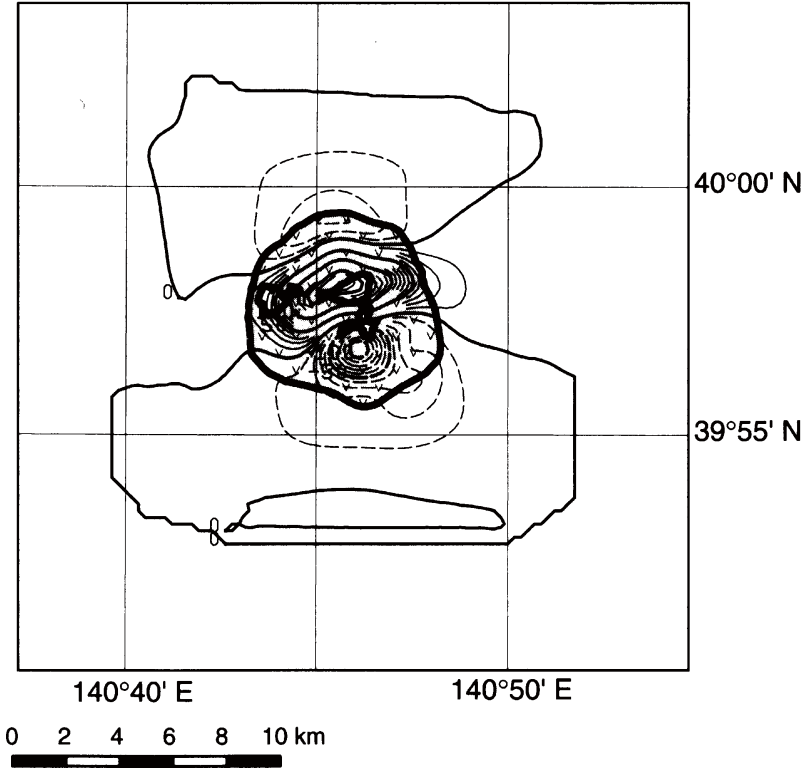

Fig. 12. Extracted total intensity aeromagnetic anomalies (IGRF residuals) of Akita-Yakeyama volcano. The anomalies were calculated from prism models within a thick solid line in Fig. 10, which have own magnetization intensities in Fig. 11 and have a flat bottom at an altitude of $5 \mathrm{~km}$ below sea level. Contour interval is $10 \mathrm{nT}$. See also Fig. 11.

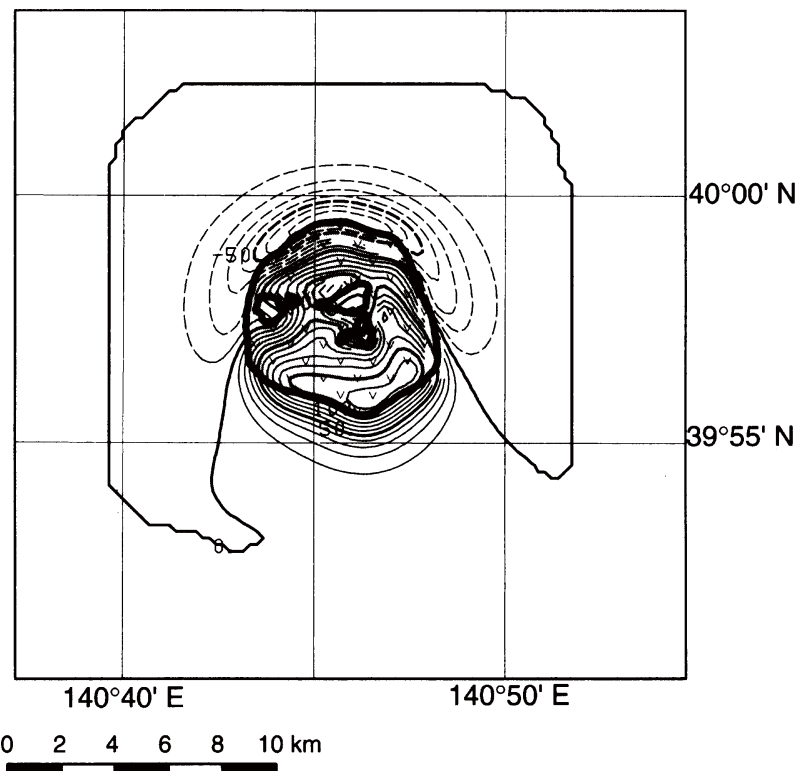

Fig. 13. Synthetic total intensity magnetic anomalies calculated from a terrain model with a boundary denoted by a thick solid line in Fig. 10. Magnetization intensity of the terrain model is assumed to be uniformly $2.0 \mathrm{~A} / \mathrm{m}$ except for the local hydrothermally altered areas which are non-magnetic. Contour interval is 10 nT. See also Fig. 11.

nic edifice (Fig. 10) were extracted from the observed anomalies (Fig. 4). The magnetic anomalies (Fig. 12) were calculated from the magnetization intensity data within an area bounded by a thick solid line (Fig. 11). Next, synthetic anomalies (Fig. 13) caused by a terrain model (Fig. 10) with a constant thickness of $500 \mathrm{~m}$ and a top corresponding to the ground surface were calculated by taking into account of the existence of hydrothermally altered areas: the altered areas were assumed to be non-magnetic. Then, residual anomalies (Fig. 14) were calculated by subtracting synthetic terrain anomalies (Fig. 13) from the extracted observed anomalies (Fig. 12). Finally, optimal synthetic anomalies (Fig. 15) were calculated to fit the extracted observed anomalies (Fig. 12) by employing five horizontal polygons (Talwani, 1965). 


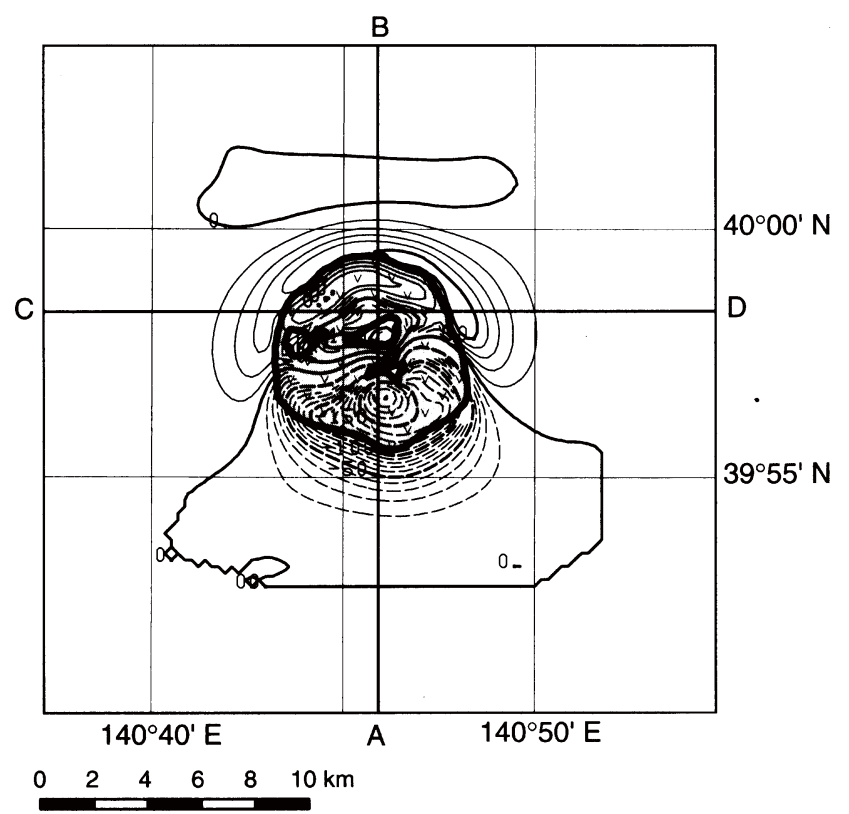

Fig. 14. Residual total intensity magnetic anomalies between the observed (Fig. 12) and synthetic magnetic anomalies (Fig. 13). Contour interval is $10 \mathrm{nT}$. See also Fig. 11.

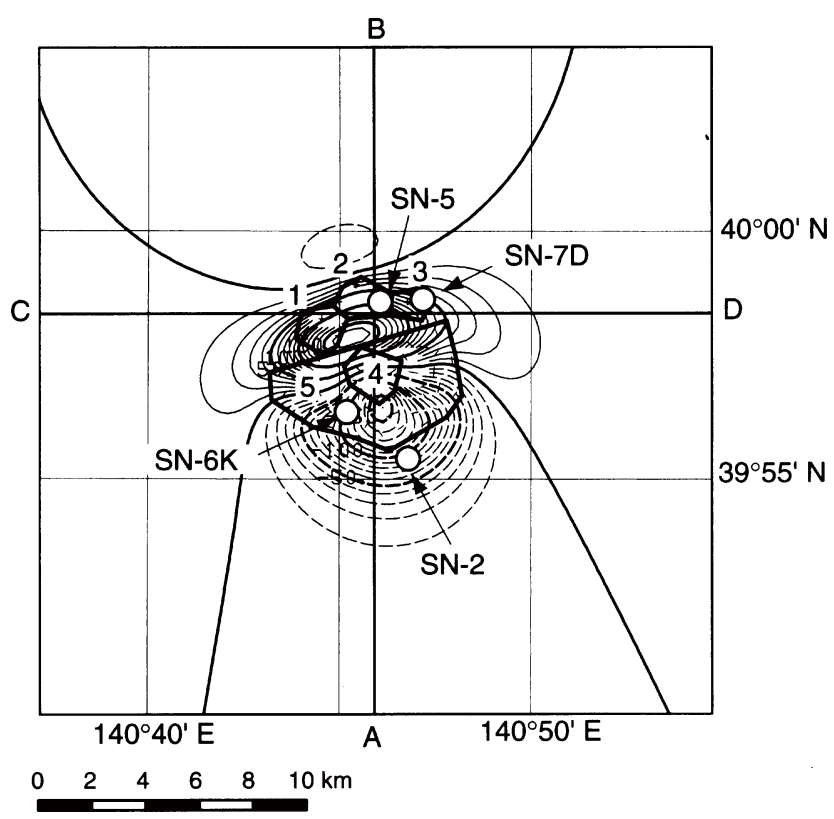

Fig. 15. Synthetic total intensity magnetic anomalies which best fit the residual anomalies (Fig. 14). Contour interval is $10 \mathrm{nT}$. Goodness-offit ratio is 1.8 . Numbers $1-5$ denote horizontal polygons. Circles show the locations of geothermal exploration wells. See also Fig. 11.

The goodness-of-fit ratio ( $r$ ) (Blakely, 1995) was employed to indicate a goodness of fittings between two data sets.

$$
r=\sum_{x=1}^{n}\left|F_{x}\right| / \sum_{x=1}^{n}\left|R_{x}\right|
$$

where, $F_{x}$ : Observed magnetic anomaly at the point of $x ; R_{x}$ : Residual anomaly between the observed and synthetic anomaly at the point of $x$.

In this equation, the larger ratio $(r)$ shows the better fitting. I employed the magnetic parameters (Table 1), determined from rock magnetic measurements (NEDO, 1986a, b; Okuma and Suto, 1987; Okuma, in preparation). The resultant magnetic model is composed of five polygons (Table 1; Figs. 15, 16(a), and 16(b)): three of them correspond to Tertiary granitic intrusions beneath the northern flank, while the rest corresponds to the reversely magnetized volcanic rocks such as the Old-Tamagawa Welded Tuffs beneath the southern flank.

\section{Discussions}

I discuss the results of the magnetic modeling for the subsurface structure of Akita-Yakeyama volcano with other information.

Tertiary granitic intrusions were found at the bottoms of geothermal exploration wells, SN-5 and SN-7D, beneath the northern flank of Akita-Yakeyama volcano but the bottom depths remain unknown. In this area, the corresponding granitic intrusions are believed to have relation to active geothermal activities; a maximum lost circulation was observed at the boundary between the intrusions and the overlaying layers, where a major geothermal reservoir is expected to exist (Nish et al., 1989). Therefore, it is important to get information about the extent of the intrusions. Polygon 1, 2 and 3 lie just inside the northern rim of the PreYakeyama caldera (Figs. 7 and 15), suggesting that the caldera collapsed along the faults between the intrusions and the surrounding layers.

Geothermal exploration wells, SN-5 and SN-7D, where high temperatures more than $200^{\circ} \mathrm{C}$ were observed, are located just above horizontal boundaries of polygon 2 and 3 , respectively (Fig. 15), implying the existence of concealed faults and fractures where hydrothermal fluids can flow easily. Resistivity models were obtained by a two-dimensional inversion of MT, EMAP (Electromagnetic Array Profiling) and CSAMT data in northern flank of AkitaYakeyama volcano (Uchida and Mitsuhata, 1995). A rather high resistivity in an order of $100 \Omega \cdot \mathrm{m}$, which corresponds to the granitic intrusions, was analyzed beneath the area and extends at least $2 \mathrm{~km}$ in a north-south direction, supporting the results of the magnetic modeling. As for geothermal explorations, boundaries between the intrusions and the surrounding layers should be a target for drilling, because fracture zones are highly expected.

The minimum bottom depths of polygon 1, 2 and 3 beneath the northern flank are about 2,000 $\mathrm{m}$ below sea level, if I fix the top depths at and around sea level on the basis of geologic information obtained from drilling (Figs. 15 and 16 ; Table 1). A temperature over $300^{\circ} \mathrm{C}$ was observed at the bottom of a geothermal exploration well, SN-7D, (NEDO, 1988), implying a demagnetization of the granitic rocks. If so, the bottom depth of these models might correspond to the local Curie depth in this area.

Geothermal activities, such as hot springs and hydrothermal alterations, are less active in the southern flank than in the northern flank of the volcano. This makes the southern flank become less attractive from a viewpoint of geothermal explorations. However, the subsurface structure of the 
(a)

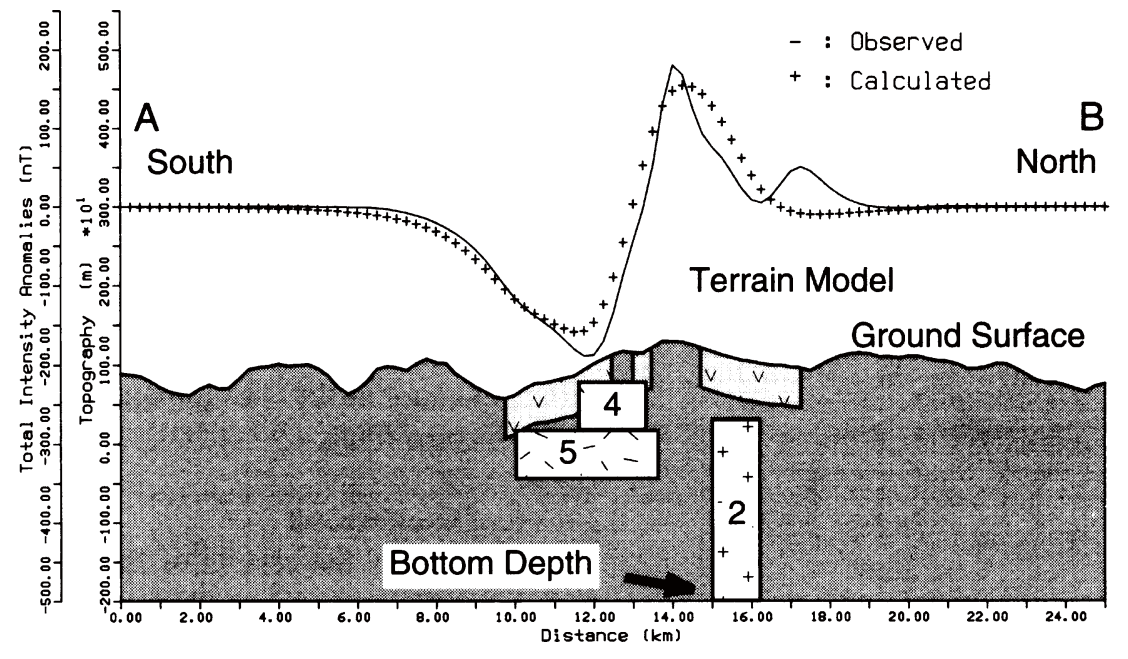

(b)

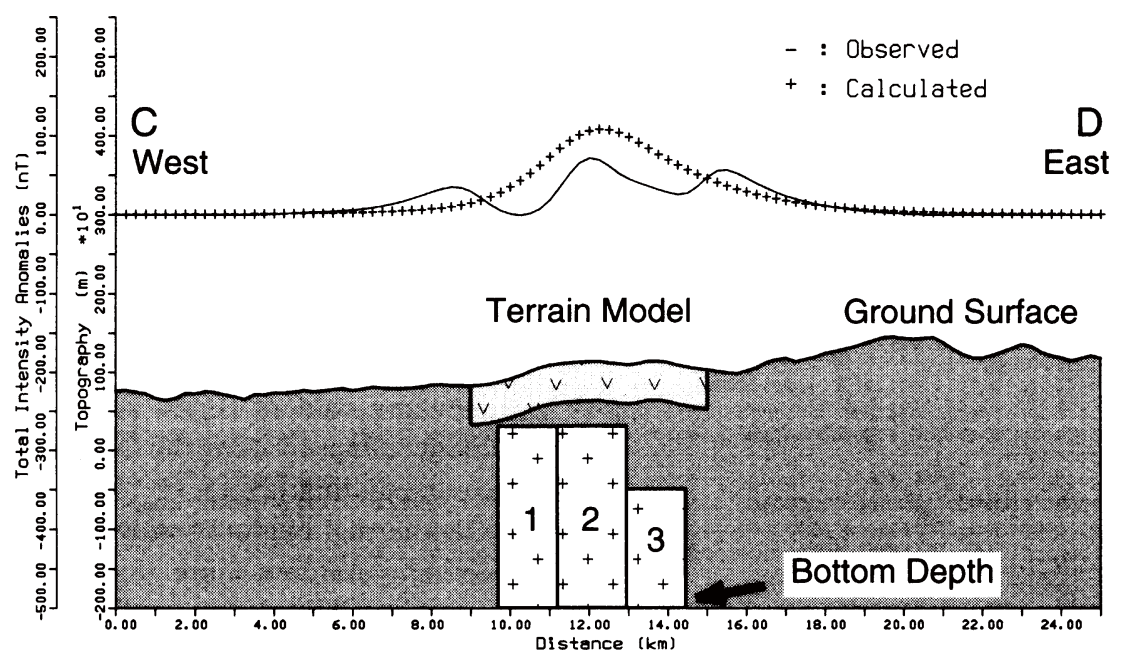

Fig. 16. (a) N-S cross section of synthetic total intensity magnetic anomalies (Fig. 15) with the magnetic model. See also Fig. 15. (b) E-W cross section of synthetic total intensity magnetic anomalies (Fig. 15) with the magnetic model. See also Fig. 15.

southern flank, as well as that of northern flank, is important to better understand how the present edifice has formed.

Two polygons 4 and 5, which are reversely magnetized, are necessary to account for the magnetic anomalies of the area (Figs. 15 and 16(a)). Polygon 5 occupies the almost southern half of the subsurface of the volcano, if I fix the top and bottom depths on the basis of geologic information obtained from drilling. This might indicate an evidence of the northern extension of the Old-Tamagawa caldera beneath the southern flank of the volcano, though the extension inferred from drilling information of SN-6K (Suto, 1992; Fig. 2) is much smaller.

I have to emphasize the existence of polygon 4, because without this it is very difficult to explain the corresponding anomalies. This result implies the existence of a concealed old volcano associated with reversely magnetized rocks such as the Old-Tamagawa Welded Tuffs and/or the PreYakeyama Andesite Pyroclastic Rocks, which were found only in drill holes such as SN-2 and SN-6K in the vicinity of the volcano (Suto, 1992; Fig. 9). Actually, a local topographic high, Kuroishimori, exists on the southern flank (Fig. 7), though the area is covered widely by Younger
Volcanic Rocks (Fig. 2). The summit of the main edifice of the volcano is located just above the northern edge of polygon 5, suggesting relationship with a concealed caldera boundary.

\section{Conclusions}

In order to better understand a regional magnetic structure, I applied an apparent magnetization intensity mapping to the magnetic anomalies in the Sengan Geothermal Area. The resultant magnetization intensity map shows that magnetization highs and lows correspond to the distribution areas of normally and reversely magnetized volcanic rocks, respectively. Magnetization lows with small amplitudes correspond to hydrothermally altered areas, suggesting a loss of magnetic minerals which compose volcanic terrain. These results lead us to a conclusion that the magnetization intensity mapping is useful for plotting the distribution of normally or reversely magnetized rocks and finding hydrothermally altered areas on Quaternary volcanic terrains.

A magnetic modeling, with known structural and magnetic parameters, was conducted to reveal a detailed subsurface structure of Akita-Yakeyama volcano. The magnetic 
model is composed of five polygons: three of them correspond to granitic intrusions beneath the northern flank, while the rest of them corresponds mainly to the buried OldTamagawa Welded Tuffs beneath the southern flank. The northern polygons show the depth extent of the granitic intrusions or the local Curie depth. The southern polygons indicate a subsurface convex structure, implying the existence of a concealed old volcano associated with the OldTamagawa Welded Tuffs and/or the Pre-Yakeyama Andesite Pyroclastic Rocks.

Acknowledgments. The author wishes to thank Shigeru Suto, Geological Survey of Japan, for his helpful criticism of the manuscript. The author also would like to express his appreciation to two reviewers, Carol Finn and Hidefumi Watanabe, for their help to improve the manuscript.

\section{References}

Bhattacharyya, B. K., Magnetic anomalies due to prism-shaped bodies with arbitrary polarization, Geophysics, 29, 517-531, 1964.

Blakely, R. J., Potential Theory in Gravity and Magnetic Applications, 441 pp., Cambridge Univ. Press, New York, 1995.

Blakely, R. J. and V. J. Grauch, Magnetic models of crystalline terrane: Accounting for the effect of topography, Geophysics, 48, 1551-1557, 1983.

Komazawa, M., Gravimetric analysis of the Sengan geothermal area, northeast Japan, Rept. Geol. Surv. Japan, 266, 399-424, 1987 (in Japanese with English abstract).

Ministry of International Trade and Industry (MITI), Compilation of aeromagnetic anomaly maps, Report on $R$ \& D of the Regional Geothermal Exploration Study, 1978.

Nakatsuka, T., Minimum norm inversion of magnetic anomalies with application to aeromagnetic data in the Tanna area, central Japan, $J$. Geomag. Geoelectr., 47, 295-311, 1995.

New Energy and Industrial Technology Development Organization (NEDO), Abstract of the Report on the 1,500 m-deep Drill Hole (N59$S N-5)$ in the Sengan Geothermal Area, 101 pp., 1986a (in Japanese).

New Energy and Industrial Technology Development Organization (NEDO), Abstract of the Report on the 1,500 m-deep Drill Hole (N59$S N-6 K)$ in the Sengan Geothermal Area, 107 pp., 1986 b (in Japanese).

New Energy and Industrial Technology Development Organization (NEDO), Abstract of the Report on the 3,000 m-deep Drill Hole in the Sengan Geothermal Area, 187 pp., 1988 (in Japanese).

Nish, Y., T. Mimura, A. Abe, S. Takagi, S. Tamanyu, and T. Noda, N61-
SN-7D Well surveys of the "Confirmation Study of the Effectiveness of Prospecting Techniques for Deep Geothermal Resources" in Sengan geothermal area, Geothermal Energy, 14, 2-26, 1989 (in Japanese).

Okubo, Y., H. Tsu, and K. Ogawa, Estimation of Curie point temperature and geothermal structure of island arcs of Japan, Tectonophysics, 159, 279-290, 1989.

Okuma, S. and S. Suto, Recompiled aeromagnetic anomaly maps of the Sengan Geothermal Area on a scale of 1:100,000, four maps, Open-file Rept. Geol. Surv. Japan, 24, 1986.

Okuma, S. and S. Suto, Magnetic structure of the Sengan geothermal area, Rept. Geol. Surv. Japan, 266, 425-447, 1987 (in Japanese with English abstract).

Okuma, S., M. Makino, and T. Nakatsuka, Magnetization intensity mapping in and around Izu-Oshima volcano, Japan, J. Geomag. Geoelectr., 46, 541-556, 1994a.

Okuma, S., A. McCafferty, and W. D. Stanley, Magnetization intensity mapping in Yellowstone national park, EOS, 75, 200, 1994b.

Research group for the geological map of Sengan Geothermal Area, Explanatory text of the geological map of Sengan Geothermal Area, scale 1:100,000, Geol. Surv. Japan, 1985 (in Japanese with English abstract, 1 p.).

Suto, S., Volcanic activity during Pliocene to Pleistocene in southern part of the Sengan (Hachimantai) geothermal area, northeast JapanPaleomagnetic study and age determination of andesite volcanoes, Bull. Geol. Surv. Japan, 36, 513-533, 1985 (in Japanese with English abstract).

Suto, S., Large scale felsic pyroclastic flow deposits in the Sengan geothermal area, northeast Japan-Tamagawa and Old-Tamagawa Welded Tuffs, Rept. Geol. Surv. Japan, 266, 77-142, 1987 (in Japanese with English abstract).

Suto, S., Explanatory text of the geological map of the central part of the Sengan Geothermal Area, scale 1:50,000, Geol. Surv. Japan, 1992 (in Japanese with English abstract, 6 p.).

Suto, S. and S. Mukoyama, Volcanic history at northern part of the Sengan geothermal area, northeast Japan, on the basis of paleomagnetic study, Rept. Geol. Surv. Japan, 266, 143-158, 1987 (in Japanese with English abstract).

Talwani, M., Computation with the help of a digital computer of magnetic anomalies caused by bodies of arbitrary shape, Geophysics, 30, 797$817,1965$.

Uchida, T. and Y. Mitsuhata, Two-dimensional inversion and interpretation of magnetotelluric data in the Sumikawa geothermal field, Japan, Rept. Geol. Surv., 282, 17-49, 1995.

White, D. E., Some principles of Geyser activity, mainly from Steam boat spring, Nevada, Am. Jour. Sci., 265, 641-684, 1967.

S. Okuma (e-mail: okuma@gsj.go.jp) 